\title{
PHILOSOPHICAL BASIS OF LEGAL REGULATION TO PROVIDE LEGAL CERTAINTY FOR CERTIFICATE HOLDERS OF BUILDING USE ON LAND MANAGEMENT RIGHTS
}

\author{
Kirnasari Hanum Masayu*, Doctoral Candidate \\ Negara Tunggul Anshari Setia, Widagdo Setyo, Permadi Iwan, Associate Professors \\ Faculty of Law, University of Brawijaya, Malang, Indonesia \\ *E-mail: hnmmasayu@gmail.com
}

\begin{abstract}
Article 1 paragraph (3) of the 1945 Constitution of the Republic of Indonesia states that the State of Indonesia is a state of law. The consequence of this article is that law is placed in the highest position in the context of state administration in the Indonesian State. In the administration of the State, the law is formed into a constitution, which is the 1945 Constitution of the Republic of Indonesia. The protection and fulfillment of human rights and the rights of citizens are at the core of the conception of the rule of law. Therefore, all legal norms that form the basis of state administration must be oriented to the protection and fulfillment of human rights and the rights of citizens. One type of land right that should be highlighted from a normative legal perspective is the Building Use Right, as stated in Article 16 paragraph (1) letter $c$ of the Basic Agrarian Law. In particular, the Right to Build is regulated in Article 35 to Article 40 of the Basic Agrarian Law. Article 35 paragraph (1) of the Basic Agrarian Law provides the meaning of Building Use Rights, namely the right to construct and own buildings on land that is not one's own, with a maximum of 30 years. Building rights comes from land that is not their own. Land that is not owned by itself is land originating from State land, land with management rights, and land with property rights. Building rights are valid for a certain period, can be extended and renewed rights. Associated with the values of Pancasila as the philosophical foundation of law in Indonesia from what is contained in the elaboration of the contradictions above, the existence of the second principle of Pancasila, just and civilized humanity, land rights are part of human rights. So the concept of humanity is a complete human being with all its dimensions including land rights which are clearly multidimensional in nature so that which must still be considered in the state regulatory system. The existence of land gives economic, political, and cultural honor/identity/self-respect functions. Therefore, the availability of a building use rights regulatory system, especially one that provides legal protection for former building use rights holders, is a manifestation of respect for human rights and humanity. Then the existence of the Fifth Precepts of Pancasila, Social Justice for All Indonesian People. This precept is the main goal or mission of living as an Indonesian state and the highest goal or crown of the legal system in a democratic country. The concept of social justice in the fifth principle of Pancasila includes justice in all its aspects and covers all human dimensions as multidimensional beings. In its preamble, the Constitution (the 1945 Constitution of the Republic of Indonesia) emphasizes the State's obligation to "... to realize a social justice for all the people of Indonesia." Therefore, Article 33 paragraph (3) of the 1945 Constitution of the Republic of Indonesia provides a legal basis as well as a philosophical and even ideological basis that the earth and water and the natural resources contained therein, the authority to regulate land is entirely left to the State as an organization of power and used for the greatest prosperity of the people. With this, the most basic legal problem is in the form of a philosophical basis for legal arrangements to provide legal certainty for holders of Building Use Rights certificates on Management Rights land. In the results of this study, the legal regulation of Building Use Rights in the context of the land law system in Indonesia also develops in the discourse of individualistic vs collectivistic values and the challenges of these developments. Reflecting on the philosophy of living together, namely Pancasila, especially the Second and Fifth Precepts, it can be seen that philosophically, the legal regulation of Building Use Rights in Indonesia is based on collective values that accept the presence of social, cultural, and economic functions from land in this country. Just and civilized humanity
\end{abstract}


and social justice for all Indonesian people are the philosophical foundations for regulating Land Rights, including Building Use Rights.

\section{KEY WORDS}

Philosophical basis, legal arrangements, legal certainty, land, management rights.

Article 1 paragraph (3) of the 1945 Constitution of the Republic of Indonesia states that the State of Indonesia is a state of law. The consequence of this article is that law is placed in the highest position in the context of state administration in the Indonesian State. In the administration of the State, the law is formed into a constitution, which is the 1945 Constitution of the Republic of Indonesia. The protection and fulfillment of human rights and the rights of citizens are at the core of the conception of the rule of law. Therefore, all legal norms that form the basis of state administration must be oriented to the protection and fulfillment of human rights and the rights of citizens.

According to J.G. Steenbeek, the constitution as the highest basic rule in a country contains at least three main things, namely: (1) the existence of guarantees and respect for human rights and citizens; (2) the establishment of a fundamental state structure of a country; and (3) the division and limitation of administrative tasks which are also fundamental. Therefore, in administering a state of law, it is necessary to have legal instruments and institutions to maintain and guarantee the protection and fulfillment of the rights of citizens. These legal instruments and institutions characterize the rule of law, which has developed both in the civil law tradition with the concept of rechtsstaat and in the common law tradition with the rule of law concept.

Philosophically, land tends to be defined as land and not soil so that land is seen in a multidimensional vision. In detail, Heru Nugroho said that land for the community has multidimensional meanings, including:

- From an economic point of view, land is a means of production that can bring prosperity;

- Politically, land can determine a person's position in community decision-making;

- As a culture that can determine the high and low social status of the owner;

- The land is sacred because it deals with inheritance and metaphysical issues.

Realizing the importance of the benefits of land for humans and being a non-renewable natural resource, the government in various policies seeks to regulate the utilization, designation, and use of land for the benefit of mankind in Indonesia. In Indonesia, the issue of agrarian resources (in a broad sense) is regulated in the constitution as Article 33 paragraph (3) of the 1945 Constitution of the Republic of Indonesia, which reads, "Earth, water and natural resources contained therein are controlled by the state and used for the greatest prosperity of the people".

The logical flow of the legal formation of the Basic Agrarian Law is clear. According to Maria SW Sumardjono, the Basic Agrarian Law is a mandate of the 1945 Constitution of the Republic of Indonesia, especially article 33 paragraph (3). The State regulates and guarantees equitable access to land for all Indonesian people. The Basic Agrarian Law is a major work published in 1960, namely in the early stages of state administration, during political conflicts, and the urgent need for a law that guarantees justice for access to obtain and utilize agrarian resources (SDA) in the form of land. Water, natural resources, and so on.

The formulation of the phrase "controlled by the state" In Article 33 paragraph (3) of the 1945 Constitution of the Republic of Indonesia, this is what became known as the concept of "The Right to Control the State" (HMN), which means control and utilization of agrarian resources is centered on power, which is so much bigger than the State. As for the relation of state control rights with the goal of the greatest prosperity of the people, it gives birth to the State's obligation to regulate:

- All forms of utilization (earth and water) and the results obtained (natural wealth) must significantly increase the prosperity and welfare of the community; 
- Protect and guarantee all the rights of the people found in or on the earth, water, and specific natural resources that can be produced directly or enjoyed directly by the people;

- Prevent all actions from any party that will cause the people not to have the opportunity or lose their rights to enjoy natural resources.

Article 4 of the Basic Agrarian Law stipulates that based on the Right to Control, the State may grant various rights to the earth's surface called land (land rights) to individuals and legal entities (as legal subjects) to be used and utilized following their designation. Rights provide prosperity and welfare for the rights holders, their families, and the surrounding community.

Article 4 of the Basic Agrarian Law paragraphs (1) and (2) are as follows: Paragraph (1) "Based on the State's Right to Control as referred to in Article 2, it is determined that there are various types of rights over the earth's surface, which called land, which can be given to and owned by people either alone or together with other people and legal entities. Paragraph (2) "The rights to land as referred to in Article 1 provide the authority to use the land in question as well as the body of the earth and water and the space above it only as necessary for interests directly related to the use of the land, within the limits of -limits according to this law and other higher legal regulations.

To clarify the Land Rights as referred to in Article 4 above, Article 16 Paragraph (1) of the Basic Agrarian Law outlines the types of land rights, including 1) Cultivation Rights; 2) Building Use Rights; 3) Right of Use; 4) Rental Rights; 5) Land Clearing Rights; 6) Right to Collect Forest Products; 7) Other rights that are not included in the rights mentioned above which will be fixed by law as well as temporary rights as mentioned in article 53 .

According to Boedi Harsono, land rights are divided into two categories, namely:

- Primary land rights. Primary land rights are rights to land obtained directly from state land;

- Secondary land rights. Secondary land rights are land rights obtained from other land rights holders based on a collective agreement.

The types of land rights that are primary are Property Rights, Cultivation Rights, Building Use Rights on State Land, and Use Rights on State Land. Types of secondary land rights are Building Use Rights on Land Management Rights, Use Rights on Land Management Rights, Building Use Rights on Land Ownership Rights, Use Rights on Land Ownership Rights, Rental Rights for Buildings, Liens Rights, Business Rights Profit Sharing, Riding Rights, and Agricultural Land Lease Rights.

One type of land right that should be highlighted from a normative legal perspective is the Building Use Right (BUILDING RIGHTS), as stated in Article 16 paragraph (1) letter $\mathrm{c}$ of the Basic Agrarian Law. In particular, the Right to Build is regulated in Article 35 to Article 40 of the Basic Agrarian Law. The provisions of Article 35 of the Basic Agrarian Law states that:

- Right to build is the right to construct and own buildings on land that is not one's own, with a maximum period of 30 years;

- At the right holder's request and taking into account the needs and condition of the buildings, the period as referred to in paragraph (1) may be extended for a maximum period of 20 years.

Article 35 paragraph (1) of the Basic Agrarian Law provides the meaning of Building Use Rights, namely the right to construct and own buildings on land that is not one's own, with a maximum of 30 years. Building rights come from land that is not their own. Land that is not owned by itself is land originating from State land, land with management rights, and land with property rights. Building rights are valid for a certain period, can be extended and can be renewed.

Currently, the latest legislation regulating Business Use Rights, Building Use Rights, Use Rights, and Rental Rights for Buildings is Government Regulation Number 18 of 2021 concerning Management Rights, Land Rights, Flat Units, and Land Registration. Nevertheless, it should be noted that even though it regulates types of land rights, Government Regulation Number 18 of 2021 concerning Management Rights, Land Rights, Flat Units, and Land Registration does not include Article 50 paragraph (2) of the Basic 
Agrarian Law. as well as the Basic Agrarian Law as a whole as part of its considerations. The Basic Agrarian Law as the juridical basis for agrarian regulation in Indonesia is still in effect. What is stated in the preamble to Government Regulation Number 18 of 2021 concerning Management Rights, Land Rights, Flat Units, and Land Registration are Article 142 and Article 185 letter b of Law Number 11 of 2020 concerning Job Creation, and remembering: Article 5 paragraph (21 of the 1945 Constitution of the Republic of Indonesia; and Law Number 11 of 2020 concerning Job Creation (State Gazette of the Republic of Indonesia of 2020 Number 245, Supplement to the State Gazette of the Republic of Indonesia N. 6573).

Building Use Rights in Government Regulation Number 18 of 2021 concerning Management Rights, Land Rights, Flat Units, and Land Registration is regulated in Part Two starting from article 34 to article 48. The following is a brief description of the arrangement of Building Use Rights according to Government Regulation Number 18 of 2021 concerning Management Rights, Land Rights, Flat Units, and Land Registration. According to Article 34 of Government Regulation Number 18 of 2021 concerning Management Rights, Land Rights, Flat Units, and Land Registration, Building Use Rights are granted to: a. Indonesian citizens; and b. a legal entity established under Indonesian law domiciled in Indonesia. Furthermore, Article 35 of Government Regulation Number 18 of 2021 concerning Management Rights, Land Rights, Flat Units, and Land Registration determines:

- Holders of building use rights that no longer meet the requirements as referred to in Article 34 within 1 (one) year must relinquish or transfer building use rights to other parties who meet the requirements;

- If the rights are not relinquished or transferred within the period as referred to in paragraph (1), then the rights are nullified by law.

For the period, Article 37 of Government Regulation Number 18 of 2021 concerning Management Rights, Land Rights, Flat Units, and Land Registration stipulates that the maximum period of 30 years is extended for state land and land management rights 30 years. Twenty years and renewed for a maximum period of 30 years (paragraph 1). As for the land with the right of ownership, the Right to Use Building period is given for a maximum period of 30 years and can be renewed with a deed of granting the right of building above the right of ownership (paragraph 2). Furthermore, according to article 36, the land that can be granted a Building Use Right includes State Land, Land with Management Rights, and Land with Ownership Rights. In total, the provisions of Article 37 of Government Regulation Number 18 of 2021 concerning Management Rights, Land Rights, Flat Units, and Land Registration are as follows:

1. Building use rights on State Land and Management Rights Land are granted for a maximum period of 30 (thirty) years, extended for a maximum period of 20 (twenty) years, and renewed for a maximum period of 30 (three) years. twenty) years;

2. The right to use the building on the land with the right of ownership is granted for a maximum period of 30 (thirty) years and can be renewed by a deed granting the right to the building on the right of ownership;

3. After the period of granting, extension, and renewal as referred to in paragraph (1) ends, land with building rights will return to Land Controlled Directly by the State or Land with Management Rights;

4. Land Controlled Directly by the State as referred to in paragraph (3), reorganizing the use, utilization, and ownership becomes the authority of the Minister. It can be given priority to former rights holders by taking into account;

5. The land is still being cultivated and utilized properly under the circumstances, nature, and purpose of granting rights.

The conditions for granting rights are fulfilled properly by the rights holders;

- Rightsholders still meet the requirements as rights holders;

- The land is still under the spatial plan;

- Not used and planned for the public interest;

- Natural resources and the environment;

- State of the land and surrounding communities. 
Meanwhile, building rights on proprietary land occurs through the granting of rights by the holder of the property rights with a deed made by the Land Deed Making Officer ("PPAT") (article 38 paragraph (3) PP 18/2021). The building rights are binding on third parties since they are registered with the Land Office (article 39 paragraph (3) PP 18/2021). Furthermore, the building rights holder has then given a Certificate of Land Rights as proof of rights (article 39 paragraph (4) PP 18/2021).

According to Parlindungan, the Building Utilization Right includes the conditions for granting, and every transfer and annulment of the right must be registered. The registration is a strong means of proof regarding the annulment of building rights and the legality of the transfer of rights, except if the rights are nullified because the period is over.

Even though the building rights is regulated in the Agrarian Law within the framework of the State's Right to Control, which is both based on Article 33 paragraph (3) of the 1945 Constitution of the Republic of Indonesia, which is now regulated in detail in PP 18/2021, this does not necessarily guarantee that in the process of establishing to the implementation of laws and regulations related to cultivation rights, every legal subject holding a cultivation right will get adequate, clear and definite legal protection considering the complexity of its implementation which is faced with various provisions and even other interests.

Associated with the values of Pancasila as the philosophical foundation of law in Indonesia from what is contained in the elaboration of the contradictions above, the existence of the second principle of Pancasila, just and civilized humanity, land rights are part of human rights. So the concept of humanity, according to this second precept, the concept of humanity is a complete human being with all its dimensions, including multidimensional land rights, so that which must still be considered in the state regulatory system. The existence of land gives economical, political, and cultural honor/identity/selfrespect functions. Therefore, the availability of a building use rights regulatory system, especially one that provides legal protection for former building use rights holders, is a manifestation of respect for human rights and humanity. Then the existence of the Fifth Precepts of Pancasila, Social Justice for All Indonesian People. This precept is the main goal or mission of living as an Indonesian state and the highest goal or crown of the legal system in a democratic country. The concept of social justice in the fifth principle of Pancasila includes justice in all its aspects and covers all human dimensions as multidimensional beings. In its preamble, the Constitution (the 1945 Constitution of the Republic of Indonesia) emphasizes the State's obligation to, "... to realize a social justice for all the people of Indonesia." Therefore, Article 33 paragraph (3) of the 1945 Constitution of the Republic of Indonesia provides a legal basis as well as a philosophical and even ideological basis that the earth and water and the natural resources contained therein, the authority to regulate land is entirely left to the State as an organization of power and used for the greatest prosperity of the people. Clarity and certainty of legal protection for holders of Building Use Rights are a form of realizing social justice. In addition, the principle of social justice in the economy (economic democratization) and people's prosperity (bonum commune) according to article 33 of the 1945 Constitution of the Republic of Indonesia. -principles of democracy and the economic field that is full of competition to achieve mutual prosperity. Clear legal protection for the holders of Building Use Rights shows a democratic space in the economic activities of the holders of these rights.

The linkage and coherence of the laws and regulations governing land tenure and rights in Indonesia by prioritizing the basic principles of social justice can reconstruct a just land law system and guarantee legal certainty for land rights holders, especially holders of Building Use Rights whose validity period has expired. A systematic and comprehensive study of the legal norms governing the legal protection of holders of Building Use Rights is part of the effort to build a straight agrarian law logic. So that the embodiment of legal protection for holders of Building Use Rights based on clear and comprehensive norms is a form of taking part in efforts to realize social justice through the use of land rights as an important asset for the State and Indonesian citizens, with this, the most basic legal problem is in the form of a philosophical basis for legal arrangements to provide legal certainty for holders of Building Use Rights certificates on Management Rights land. 


\section{METHODS OF RESEARCH}

The type of research used is normative juridical, namely research on legal principles contained in legislation and court decisions. The nature of this research is analytical descriptive by describing the facts regarding the granting of building use rights over management rights. This study combines three approach methods, namely the statutory approach, the conceptual approach, the approach by analyzing statutory data is carried out by collecting and then analyzing and concluding the contextualization with the subject matter. In contrast, the conceptual approach is carried out by collecting opinions. -opinions of legal experts to answer existing problems. Types of legal materials use 3 (three) primary legal materials, secondary legal materials, and tertiary legal materials. Sources of data used in this study are primary data and secondary data. The analysis of legal materials used is qualitative prescriptive, namely to provide arguments for the research results that have been carried out.

\section{RESULTS AND DISCUSSION}

Grammatically, the land is a part of the earth called the earth's surface, which Agrarian Law governs. Based on the Big Indonesian Dictionary, Land has several meanings: (Language Development and Development Agency of the Ministry of Education and Culture (Language Center), http://kbbi.web.id/tanah):

- The surface of the earth or the layer of the earth that is above;

- The State of the earth somewhere;

- The delimited surface of the earth;

- Mainland;

- The limited surface of the earth that is occupied by a nation that is ruled by a state or becomes a state territory;

- Materials from the earth, the earth as the material of something (sand, marl, rock, etc.);

- Basic (color, paint, and so on).

Some understanding of this soil, which is appropriate in this study, is the earth's surface or the layers above.

The land is part of the source of human life. Therefore, land for Indonesian people is not only an inanimate object to stand, live and grow crops. Indonesians who actually have an agricultural background view and believe in the land where they live as part of themselves, their name and dignity. For this reason, owning land in the context of Indonesian socioanthropology is closely related to self-esteem (social values), sources of income (economic values), power, and privileges (political values). Land for the people of Indonesia is a very concrete thing, which is related to houses, rice fields, fields, villages, villagers, farmers, and so on in all aspects: social, economic, cultural, political and even religious (Rachman, 2015)

From a philosophical perspective, land has a very fundamental relationship with humans. In terms of the Abrahamic religions, man is from God and will return to God to his foundation, namely the earth. Because according to the origin of the human creation process is from the ground, then the end of his life will return to the soil from the ground back to the ground. Thus, the relationship between humans and or society with this land is eternal. Further understanding that the real source of economic and political resources in society is land, in a broad sense, including hereditary use.

Based on this, it can be seen that the existence of community life with the land is a relationship between the land and its rulers, in this case, the customary law community, in their daily life, carrying out their activities based on different rules and norms under the adopted traditions. by each customary law community which is scattered throughout the soul of the Indonesian nation.

In sociological studies, the land is one of the factors that determine a person's social stratification. This happens because the land is something that is "valued". As long as there 
is something that is valued in society - and every society must have something that it values - then that thing will become the seed that grows a multi-layered system in that society (Soekanto, 1977).

In the juridical context, the land is understood as the earth's surface, while land rights are rights to a certain part of the earth's surface, which is limited, has two dimensions with length and width. From a legal perspective, the land is studied based on land tenure rights as a legal system. This means how the law views land issues related to land tenure rights in a system. As a system, land rights must be seen as a value. Because the law is the embodiment of values, the regulation of land tenure and ownership means that its presence is to protect and promote values that are upheld by the community, so the control and ownership of land rights must be protected.

The study of land rights from the perspective of legal science means discussing land rights from control and ownership. The position of land in these different value systems, when viewed from the study of the philosophy of law, the land contains different values, depending on the place and time in which the value system grows and develops. The difference in the value system results in differences in the land law system. In addition, the influence of economic, political, and legal factors has resulted in a tendency to impose certain values on other values, which leads to the deconstruction and reconstruction of certain land law systems.

With a legal philosophy approach, the nature of land and land rights will be sought and what is behind the land and land rights, as well as investigating legal rules as value considerations. Thus philosophically, control and ownership of land are loaded with values that underlie the birth of legal norms governing control and ownership of land in which there are authority, rights and obligations, and power.

In human life, the existence of land will not be separated from all humans' actions because the land is a place for humans to live and continue their lives. Therefore, the land is needed by every member of the community so that disputes often occur among each other, especially those concerning land. For this reason, rules are needed that regulate the relationship between humans and the land.

Ontologically, the existence of land ownership rights in Indonesia can be understood in the context of the philosophy of Pancasila as the basis of the State and the source of all sources of law in Indonesia, especially the second and fifth precepts. Human Rights in Indonesia originated and led to Pancasila. This means that human rights get a strong guarantee from the nation's philosophy, namely Pancasila. Leading to Pancasila, it is intended that the implementation of these human rights must pay attention to the lines that have been determined in the provisions of the Pancasila philosophy. For the Indonesian people, implementing human rights does not mean carrying out freely, but must pay attention to the provisions in the Indonesian nation's view of life, namely Pancasila. This is because there are no rights that can be exercised in absolute terms without regard to the rights of others.

The second principle of Pancasila, just and civilized humanity provides the basis that land rights are part of human rights. So the concept of humanity is a complete human being with all its dimensions including land rights which are clearly multidimensional in nature so that which must still be considered in the state regulatory system. The existence of land gives economical, political, and cultural honor/identity/self-respect functions. Therefore, the availability of a building use rights regulatory system, especially one that provides legal protection for former building use rights holders, is a manifestation of respect for human rights and humanity. The second principle of Pancasila places the rights of every citizen in the same position under the law. It has the same obligations and rights to obtain legal guarantees and protection.

Likewise, Pancasila is the fifth Precept, Social Justice for All Indonesian People. Every human being has the same rights, and every human being has the right to get the same treatment. Every Indonesian citizen must be treated fairly in obtaining and controlling land rights. Men and women have the same rights to obtain property rights to land and buildings to realize an increase in their welfare. For this reason, both the owner of land and buildings 
obtained through legal events or legal actions, both actions in cash and installments/installment payments, have the same rights to obtain Property Rights status (Leksono, 2001).

Furthermore, in the Preamble of the 1945 Constitution, the Fourth Paragraph lays down the philosophical foundation as follows: "Then from that to form an Indonesian State Government that protects the entire Indonesian nation and the entire homeland of Indonesia and to promote public welfare, educate the nation's life, and participate in carrying out world order that is Based on independence, eternal peace, and social justice, the independence of the Indonesian nation is formulated in a Constitution of the Republic of Indonesia which is sovereign by the people based on: Belief in the One and Only God, just and civilized humanity, Indonesian unity, and democracy - led by wisdom in deliberation/representation and by realizing social justice for all Indonesian people.

The provisions in the fourth paragraph above show that the Government of the State of Indonesia protects the entire Indonesian nation and all of Indonesia's bloodshed and promotes the public welfare. The Government of the State of Indonesia wishes to realize social justice for all Indonesian people. Everyone must be protected by law for their rights fairly and equitably to realize the community's welfare.

The ideals of justice have been formulated by legal thinkers (Plato, Aristotle, Hans Kelsen, Herbert Spencer, W. R Sorley, Thomas Aquinas and others) resulting in the conclusion that justice demands freedom, equality, and other rights that are harmonized and protect humanity to obtain as much as possible according to the common good. Since the so-called general good is difficult to define, it is emphasized that justice has dynamic and unstable components. According to social law philosophers (such as Nietzsche, Thomas Hobbes, Immanuel Kant, John Dewey), the change in injustice occurs in line with changes in human civilization (Sudjito, 2011).

For the Indonesian people, the issue of justice is contained in the second and fifth precepts of Pancasila. This second precept is the basis for recognition from the State that humans are virtuous creatures of God, have creativity, taste and intention as creatures with potential, humans have the same basic rights and obligations in order to develop their humanity. Fair in the second precept is defined as respecting human rights, actions that are not arbitrary, and giving someone their right. The word "fair" in the fifth precept is specific in the sense of being fair to fellow human beings who are based and inspired by being fair to oneself and fair to God. Thus, the implementation of justice is always related to living together concerning other parties in social life.

The description above has explained that the ontology of land rights based on Pancasila is contained in the second and fifth precepts with the ultimate goal of justice for every human citizen. Justice as the final estuary is also the ultimate goal and even the essence of the law. Thus, philosophically, the concept of property rights over land can be discussed in the perspective of legal philosophy in general and land law in particular.

Philosophy of law is part of ethics or a branch of moral philosophy. Because what is regulated by law is human action categorized into three things: commands, prohibitions, and permits. The discussion that is the focus of discussion in legal philosophy is about the nature of law, its purpose, why it exists, and why people must submit to the law (Farkhani et al., 2018).

In addition to answering these general abstract questions, the philosophy of law also discusses concrete questions regarding the relationship between law and morals (ethics). And the problem of the legitimacy of various kinds of legal institutions even though the product of legislation orders the existence of these legal institutions. This happens when morals (ethics) have been institutionalized in a society, live, and are obeyed by all its teachings.

Philosophy of law is the terminology used to understand the law as a complete reality with a holistic approach, including metaphysical, social, and political orders. In this context, science includes values, knowledge, and skills. Values are the essential things of scienceincluding paradigms-which can be obtained through philosophy as well as theology. Value is also a legal paradigm, where the law can be seen as a value figure. Law as the embodiment 
of values implies that its presence is to protect and advance the values that are upheld by the community.

In philosophy, the fundamental conflict about the value system that occurs in an ideal of justice is the conflict between collectivism and individualism. This contradiction becomes a problem for thinkers, lawyers, and politicians. These contradictions can be summarized as follows: (1) individuals are given a place under society; (2) the community is given a place under the individual; (3) tried to combine the two founders who contradicted each other (Soetikno, 2008).

This contradiction gives rise to different models of land tenure in the history of human life. According to Notonagoro, the relationship between humans and land can be divided into three models: collectivism, individualism, or collectivism, in which there are individual rights. In addition to these three models, since the Ancient Roman era, the land outside the three models has been known as res extra commercium; namely res commune, res publicae, res sacre, and res nullius.

When Indonesia was preparing for its independence, the founding fathers were determined not to be dragged into the current ideological contradictions: individualism, socialism, and Islam. That's why the value system that becomes the national ideology is Pancasila, which contains the collectivity values of Indonesia. This value system firmly rejects the notion of individualism but accommodates various groups and understandings that exist in Indonesia.

Therefore, in forming the national agrarian law, collectivist values are used as the basis for preparing the Basic Agrarian Law (UUPA). Collectivity values provide more direction so that the common interest or part of the community gets attention in setting legal norms. Collectivity values are based on the view that the existence of society as a whole is more important than the existence of individuals. Consequently, the value of collectivity does not provide opportunities for individual interests to develop because these latter interests must be subordinated or subordinated to the common interest or the majority of society.

Understanding justice always begins with justice as well as other legal goals, namely legal certainty and expediency. Justice is not explicitly written in the text. Still, legislators have seen that in the manufacture of statutory products, it is based on justice which is part of the purpose of the law itself, as in the ethical theory that the purpose of the law is solely to realize justice (justice), which is contained in the classical theory of legal goals, while in modern priority theory the standard in modern theory is that the legal objectives include justice, expediency and legal certainty (Dwisvimiar, 2011).

In Satjipto Rahardjo's view, justice is a constitutive element of the law. Losing the value of justice from the law is losing the law itself. The characteristics of a state of law (rechsstaat) include the protection of human rights, the separation or division of powers, government based on laws and regulations (wetmatigheid van bestuur), and administrative justice in disputes. Although the spirit or philosophy of the rule of law is not the same in every country, in essence, it is not different, namely that every power holder in the State, in carrying out his duties and authorities, must base himself on the applicable legal norms, both written and unwritten. The goal is the same, namely: "the achievement and the preservation of freedom of the individual human being against the arbitrary of collective power".

Law as the embodiment of political wisdom is a regulation. Therefore the regulation is strongly influenced by the ruler's perspective on the law. When the ruler views the law as a tool of social engineering, the ruler will take public policies, which then become regulations that can be used to create a social system that can regulate and control society. The view of this ruler's law will tend to be carried out repressively (Nonet \& Selznick, 2003). The repressive law does not pay attention to the community's interests or, in other words, denies the legitimacy of the community. At first glance, the law appears to be followed by community compliance. Still, the value of community compliance that arises is false because the value of community compliance is based on the fear of severe legal sanctions.

Justice must be formulated at three levels, namely outcome, procedure, and system. Here, the assessment of justice depends not only on the size of something obtained 
(outcome), but also on how it is determined and the system or policy behind it. Outcomerelated justice is often referred to as distributive justice, but the two things are not the same.

The concept of social justice is different from legal justice, political justice, economic justice, individual justice, and so on. But the concept of social justice, of course, also does not only concern the issue of morality in social life, which varies from one culture to another. However, the whole idea of justice can eventually be covered by and culminate in the idea of social justice.

Social justice must indeed be distinguished from various dimensions of justice, such as legal justice, political justice, economic justice, and so on. However, it can also be understood that the whole idea of justice can ultimately be covered by and culminate in the idea of social justice. Because in the end, legal justice and economic justice must produce the final result in realizing social justice for all. It contains the understanding that (i) the injustice that has existed so far must be addressed to the lowest point, (ii) Redistribution of wealth, power, and status of individuals, communities, and social wealth (societal good), and (iii) the State c.q. The government is responsible. The government is to ensure the basic quality of life for all its citizens. In essence, social justice is the pinnacle of collective social welfare in a country and a region.

The embodiment of justice and social justice in law is the main, fundamental, and most complex, broad, structural, and abstract element. This condition is due to the concept of justice and social justice, which contains the meaning of protection of rights, equality and position before the law, public welfare, and the principle of proportionality between individual interests, social interests, and the State. Justice and social justice cannot always be born from rationality but are also determined by the social atmosphere which is influenced by other values and norms in society. The legal arrangement for the holder of the Right to Build has a philosophical foundation in the vision of the rule of law to realize social justice for all the people of Indonesia.

Law has a very big role in social life in society. The great role of law can be seen in order, peace, and the absence of tension in society, because law regulates, determines rights and obligations, and protects individual interests and social interests. In the context of social life, the law runs in such a way that the relationship can run in an orderly and orderly manner because the law explicitly determines clear duties, obligations, and authorities so that relationships in social life can run smoothly because each of them knows what their rights and obligations are.

To that end, A.G. Peter (Vego, 1991) suggests that there are three perspectives to be able to see the function of law, namely: First, the perspective of social control from the law which is one of the most widely used concepts in social studies. A.G. Peter argues that the position of law as a tool of social control can be seen from its function in society. In this perspective, it can be said that no society can live forever without social control from the law as a means. Second, the social engineering perspective, which is the review that is most widely used by officials to explore what sources of power can be mobilized using law as a mechanism, and to realize mobilization with the law as a tool, there are main prerequisites that must be met in order for the rule of law is classified as an engineer, namely: a good description of the situation at hand, analysis of assessments and determining values, verification of hypotheses, and measurement of the effects of applicable laws. Third, the perspective of community emancipation towards the law. This perspective is a bottom-up review of the law, which includes the object of study, such as the ability of the law to support community aspirations, legal culture, legal awareness, law enforcement, and others.

\section{CONCLUSION}

Ontologically, the nature of the land is inherent in human existence on earth. Operationally, this nature is expressed by the formulation that land is part of the source of human life. Therefore, land for Indonesian people is not only an inanimate object to stand, live and grow crops. Land in Indonesian society has a multidimensional meaning, both in terms of economy, politics, law, and socio-culture. Therefore, philosophically, control and 
ownership of land are loaded with values that underlie the birth of legal norms governing control and ownership of land in which there are authority, rights and obligations, and power. In the Indonesian context, the epistemological and axiological aspects of legal arrangements for Land Rights, including Building Use Rights, are the values of Pancasila and the 1945 Constitution of the Republic of Indonesia.

In the juridical context, the land is understood as the earth's surface, while land rights are rights to a certain part of the earth's surface, which is limited, has two dimensions with length and width. From a legal perspective, the land is studied based on land tenure rights as a legal system. This means how the law views land issues related to land tenure rights in a system. As a system, land rights must be seen as a value.

The second principle of Pancasila, just and civilized humanity provides the basis that land rights are part of human rights. So the concept of humanity is a complete human being with all its dimensions including land rights which are clearly multidimensional in nature so that which must still be considered in the state regulatory system. The existence of land gives economical, political, and cultural honor/identity/self-respect functions. Therefore, the availability of a building use rights regulatory system, especially one that provides legal protection for former building use rights holders, is a manifestation of respect for human rights and humanity. Human rights are basic rights that humans have had since they were born. Human rights can be formulated as inherent rights in our nature as human beings. Without these rights, we can't live as human beings. This right is owned by humans solely because they are human beings, not because they are given by society or the State. Human rights are rights that humans have that have been obtained and brought along with their birth in the life of society. The second principle of Pancasila places the rights of every citizen in the same position under the law. It has the same obligations and rights to obtain legal guarantees and protection.

Likewise, Pancasila is the fifth Precept, Social Justice for All Indonesian People. Every human being has the same rights, and every human being has the right to get the same treatment. Every Indonesian citizen must be treated fairly in obtaining and controlling land rights. Men and women have the same rights to obtain property rights to land and buildings to realize an increase in their welfare. Collectivity values are used to prepare the Basic Agrarian Law, which is the basis for land law in Indonesia. As a basic law, the collectivity value contained in the Basic Agrarian Law is intended to animate other laws governing agricultural matters and laws related to agrarian matters.

The legal arrangement of Building Use Rights in the context of the land law system in Indonesia also develops in the discourse on individualistic vs. collectivistic values and the challenges of capitalism. Reflecting on the philosophy of living together, namely Pancasila, especially the Second and Fifth Precepts, it can be seen that philosophically, the legal regulation of Building Use Rights in Indonesia is based on collective values that accept the presence of social, cultural and economic functions from land in this country. Just and civilized humanity and social justice for all Indonesian people are the philosophical foundations for regulating Land Rights, including Building Use Rights.

Understanding justice always begins with justice as well as other legal goals, namely legal certainty and expediency. Justice is not explicitly written in the text. Still, legislators have seen that in the manufacture of statutory products, it is based on justice which is part of the purpose of the law itself, as in the ethical theory that the purpose of the law is solely to realize justice, which is contained in the classical theory of legal goals, while in modern priority theory, the standard in modern theory is that the legal objectives include justice, expediency, and legal certainty.

\section{REFERENCES}

1. Hajati, S. \& Sekarmadji, A (2011). Buku Ajar Politik Hukum Pertanahan. Surabaya: Pusat Penerbitan dan Percetakan Unair.

2. Harsono, B (1994). Hukum Agraria Indonesia, Sejarah Pembentukan Undng-Undang Pokok Agraria, Isi dan Pelaksanaannya. Jakarta: Djambatan. 
3. Mertokusumo, S (1988). Hukum dan Politik Agraria. Jakarta: UT.

4. Rahardjo, S (2007). Membedah Hukum Progesif. Jakarta: Kompas Gramedia.

5. Rahardjo, S (2008). Ilmu Hukum Di Tengah Arus Perubahan. Malang: Surya Pena Gemilang.

6. Soekanto, S. \& Purbacaraka, P (1993). Perihal Kaidah Hukum. Bandung: Citra Aditya Bakti.

7. Soetiksno (2008). Filsafat Hukum Bagian I. Jakarta: Pradnya Paramita.

8. Sudjito (2011). Hukum Progresif untuk Mewujudkan Keadilan Substantif dalam Bingkai Nilai-Nilai Pancasila. Jakarta: UGM dan Sekjen MK.

9. Vego, S (1991). Law and Society. New Jersey: Prentice Hall.

10. http://kbbi.web.id/tanah 